\title{
Environmentally Clean Ceramics Manufacturing With Application of Hazardous Car Production Mud and Galvanic Process Glass Waste
}

\section{Vsevolod Mymrin ( $\square$ seva6219@gmail.com )}

Universidade Tecnologica Federal do Parana - Campus Medianeira

\section{Kirill Alekseev}

Universidade Tecnologica Federal do Parana - Campus Medianeira

Monica A. Avanci

Universidade Tecnologica Federal do Parana - Campus Medianeira

\section{Paulo H.B. Rolim}

Universidade Tecnologica Federal do Parana - Campus Medianeira

Cleber L. Pedroso

Universidade Tecnologica Federal do Parana - Campus Medianeira

Daniela E. Pedroso

Universidade Tecnologica Federal do Parana - Campus Medianeira

\section{Research Article}

Keywords: car production mud, red ceramics, mechanical properties, structure formation processes, environmentalle clean production

Posted Date: July 6th, 2021

DOl: https://doi.org/10.21203/rs.3.rs-661166/v1

License: (c) (i) This work is licensed under a Creative Commons Attribution 4.0 International License. Read Full License 


\section{Abstract}

It was developed new ceramics composites with hazardous car production mud (CPM) and galvanic process glass waste with high content of heavy metals. They were applied as valuable components of red ceramics sintered at $700^{\circ}, 750^{\circ}, 800^{\circ}, 850^{\circ}, 900^{\circ}$, and $950^{\circ} \mathrm{C}$ to provide flexural resistance of up to $17.6 \mathrm{MPa}$, water absorption at $950^{\circ} \mathrm{C} 6.53-10.45 \%$, linear shrinkage $-5.24-6.29 \%$, density $2.7-3.2 \mathrm{~g} / \mathrm{cm}^{3}$, and dilatation coefficient $5.3-13.8 \%$. Structure formation studies by the XRD, SEM, EDS, and LAMMA methods demonstrated the synthesis of amorphous glassy material with small inclusion of mullite $\mathrm{Al}_{6} \mathrm{Si}_{2} \mathrm{O}_{13}$. Car production mud and galvanic process glass waste play the role of the intensifiers of the ceramics' structures formation processes. The ceramics' leaching and solubility tests by the atomic absorption spectroscopy method showed strong chemical bond of heavy metals of the hazardous raw materials in insoluble structures. According to Brazilian standards, they can be used to produce tiles, bricks, blocks, and similar materials with high environmental eficiency.

\section{Introduction}

Car production mud (CPM) usually contains a relatively high amount of galvanic wastes; therefore, high levels of heavy metals characterize it, such as the extremely hazardous environmental pollutants - $\mathrm{Ni}, \mathrm{Zn}, \mathrm{Cr}$, $\mathrm{Sn}, \mathrm{Cu}, \mathrm{Pb}, \mathrm{Sb}$, among others (Szyczewski, 2009). There are many published studies on methods (ElAshtoukhy, et al, 2020) and effectiveness (Kołodyńska D et al, 2020) of heavy metals adsorption from diverse industrial wastes. The main disadvantages of these methods are the shortfall in the heavy metals' separation and the additional contamination of materials by the chemical reagents introduced to implement these processes, thus, polluting the materials and the environment (Fraissler et al,2009). To solve ecological problems, these types of wastes should be utilized as efficient raw materials to produce environmentally clean and economically attractive ceramics, such as bricks and paving tiles (Usai, 2003). Barreto et al. (2020) formulated a composition for Solidification and Stabilization (S/S) of galvanic solid waste, concomitantly with ornamental rocks solid waste. Basegio et al (2001) studied the possibility of utilizing high heavy metal content tannery waste in mixtures with natural clay. Solubility and leaching tests resulted in a recommendation of only $10 \%$ of such waste. Anhydrous calcium silicate and sulfoaluminate were synthesized using a mixture containing powdered tuff, bauxite, calcium carbonate, and sulfate. Asavapisit and Chotkland (2004) tried to bind galvanic mud using a mixture of lime and pulverized fuel ash ( $30 \%$ and $70 \%$, respectively) activated by adding up to $8 \% \mathrm{Na}_{2} \mathrm{SiO}_{3}$ or $\mathrm{Na}_{2} \mathrm{CO}_{3}$.

Zhu et al. (2016) elaborated ceramics with low density and low thermal conductivity from glass waste (GW) with coal fly ash, borax, and calcium carbonate; Wei et al (2014) also used a mix of waste glass and coal fly ash to prepare lightweight aggregates.

Bai, et al (2014) developed foams from GW and fly ash with a density of $0.267 \mathrm{~g} / \mathrm{cm}^{3}$, compressive resistance of $0.98 \mathrm{MPa}$, and porosity of $81.55 \%$. Ji, et al (2019) applied GW as the primary raw material in composites with mineral wool waste to produce low-temperature glass foam.

Phonphuak, et al. (2016) added 10\% glass waste to clay brick to decrease the firing temperature by almost $100^{\circ} \mathrm{C}$. Mymrin, et al (2015) developed sustainable ceramic materials with low sintering temperatures and a 
glass-like structure, applying glass scrap to composites with paper production sludge. Kim, et al. (2015) substituted feldspar with liquid crystal from GW to produce porcelain sanitary ware. Ye, et al (2015) presented a gold and cooper tailings treating method by sintering glass-ceramics.

Lu, et al. (2019) developed precast concrete from glass cullet and glass powder. Gorospe, et al (2019) studied the effect of various glass aggregates on plastic and drying shrinkage and the expansion of the alkali-silica reaction of cement mortar. Starý, et al. (2019) created a new, advanced, and, above all, ecological mechanical glass frosting technology to reduce the once-clear soda-lime glass' transparency using an abrasive roller brush with composite filaments.

This brief review of the literature demonstrates the variety of guidelines for the disposal of industrial waste with a high content of heavy metals. Considering the continuous growth in the amount of industrial waste with a high content of heavy metals discarded and the low percentage of their use, there is an urgent need to develop new compositions to provide them an ecological and economically attractive destination.

Therefore, the goals of this research were to develop new sustainable materials and methods at the laboratory level for utilizing hazardous industrial car production mud with a very high content of heavy metals and different organic wastes; to use as secondary materials metals surface cleaning glass waste formed as a result of metal surfaces cleaning prior to their galvanization process, and traditional clay-sand mix from a ceramic production plant; to study the physical and chemical characteristics of these raw materials; to study the mechanical and physical properties of the developed materials and the processes of their structure formation; to study the environmental impact of the developed materials and their compliance with Brazilian sanitary standards.

\section{Materials And Methods}

All raw materials under study were obtained from local industrial enterprises of Paraná state, Brazil, namely automobile production mud (CPM) and glass waste (GW) from metal cleaning before the galvanic process. The third component used to develop the red ceramics was a mixture of red pottery clay with sand (CSM) - a traditional mix of natural raw materials from a local brick plant. The materials samples were prepared by homogenizing the initial components' mixtures at their natural humidity and compressing them at $10 \mathrm{MPa}$. The wet rectangular samples sized $60 \times 20 \times 10 \mathrm{~mm}$. After drying to constant weight at $100^{\circ} \mathrm{C}$, the samples were sintered for 6 hours at different temperatures $\left(700^{\circ}, 750^{\circ}, 800^{\circ}, 850^{\circ}, 900,950^{\circ}\right.$, and $\left.1000^{\circ} \mathrm{C}\right)$ corresponding to the actual firing range in local brick plants.

\subsection{Methods}

The raw materials and ceramics were characterized by several complementary methods. Chemical compositions were studied by X-ray fluorescence (XRF) in a Philips/Panalytical PW 2400; mineral compositions - by X-ray diffraction (XRD) in a Philips PW 1830; morphological structures - by scanning electron microscopy (SEM) in an FEI Quanta 200 LV microscope; chemical microanalyses - by energy dispersive spectroscopy (EDS) in an Oxford (Penta FET-Precision) X-ACT spectrometer; solubility and 
lixiviation of metals from liquid extracts - by the atomic absorption analysis (AAA) method in a Perkin Elmer 4,100 spectrometer; granulometric compositions - by particle size distribution analysis by laser diffraction in an LA-950 HORIBA Analyzer; mechanical resistances - by three-point flexion strength (FS) on an EMIC universal testing machine; water absorption (WA) - on an Instrutherm BD 200; linear shrinkage (LS) - on a Mitutoyo; density measurements. The values of the mechanical properties and standard deviations were obtained as an average of 10 samples' measurements.

\subsection{Calculations}

The samples' flexural rupture strength was measured according to the Brazilian standards NBR 15,270-3 (2005), which uses the following equation: $\mathrm{Rf}=3 \mathrm{PL} / \mathrm{bh}^{2}(1)$

where: Rf - flexural rupture resistance (MPa), P - maximum load supported by the specimen (kgf), L - the distance between the supports of the specimen ( $\mathrm{mm})$; b - sample width ( $\mathrm{mm}), \mathrm{h}$ - sample height (mm).

The water absorption values were measured according to the same standard with the following equation: $\mathrm{W}_{\mathrm{A}}$ $=\left[\left(M_{S A T}-M_{D}\right) / M_{D}\right] \times 100(2)$

where $M_{S A T}$ is the water mass that saturated the specimen after 24 -hour water immersion and $M_{D}$ is the dry specimen mass after sintering.

\section{Results And Discussion}

\subsection{Raw materials' characterization}

To achieve the goal of improving the mechanical and physical properties of ceramics, the particle size distribution, chemical, and mineralogical compositions, and micro-morphological structure of the raw materials were studied.

\subsubsection{Particle size distribution of the raw materials}

The particle size distribution of the raw materials showed that the vast majority (84.42\%) of CPM particles had sizes from 0.30 to $1.19 \mathrm{~mm}$. Conversely, most of the GW particles (64.27\%) presented sizes between 0.15 and $0.29 \mathrm{~mm}$. The CSM was mainly composed $(88.62 \%)$ by the smallest particles among the studied raw materials ( 0 and $0.074 \mathrm{~mm}$ ). The most humid (58.32\%) was CPM, and the driest and most dense (2.68 $\mathrm{g} / \mathrm{cm}^{3}$ ) was GW, followed by CSM with $1.63 \mathrm{~g} / \mathrm{cm}^{3}$ density.

\subsubsection{Chemical composition of the raw materials}

CPM's chemical composition consisted mainly of $\mathrm{Cr}-28.53 \%, \mathrm{Zn}-20.28 \%, \mathrm{Cu}-3.78 \%$, and a

calcination loss (C.L.) - 39.11\%. Furthermore, it had many other heavy metals (Cu, Se, Co, Ni, W, Sn, and Pb), each in contents between $0.21-0.67 \%$, totaling $1.97 \%$. Thus, the significant number of heavy metals present and their high content allows it to be classified as a Class 1 hazardous material (NBR 10,004, 2004). 
C.L. can be explained by the presence of organic components (mainly pitches, oils, paints, inks). Glass waste (GW) had a typical chemical composition of glass - mainly $\mathrm{SiO}_{2}-69.33 \%, \mathrm{CaO}-7.46 \%, \mathrm{Na}_{2} \mathrm{O}-10.13 \%$, and $\mathrm{K}_{2} \mathrm{O}-8.50 \%$; it also contained heavy metals, but in a relatively small quantity $-\mathrm{Zn}-0.07 \%, \mathrm{~Pb}$ and $\mathrm{Sr}-$ $0.02 \%$, with negligible C.L. $=0.45 \%$.

Chemical composition of the clay-sand mix (CSM) was very common for these natural materials:

$\mathrm{SiO}_{2}-54.58$ wt. $\%, \mathrm{Al}_{2} \mathrm{O}_{3}-21.40 \%, \mathrm{Fe}_{2} \mathrm{O}_{3}-8.33 \%, \mathrm{~K}_{2} \mathrm{O}-4.98 \%, \mathrm{MgO}-1.53 \%$ and C.L. $=7.91 \%$ mainly due to organics firing and carbonate dissociation.

\subsubsection{Mineral composition of the raw materials}

The deciphered XRD pattern showed (Figure 1) a content of mainly amorphous materials in the components' dry mix sample with significantly small peaks of the main components of the natural clay-sand mix - clay mineral illite $\mathrm{KAl}_{2} \mathrm{Si}_{3} \mathrm{AlO}_{10}(\mathrm{OH})_{2}$ and quartz $\mathrm{SiO}_{2}$ with a high content of magnetite $\mathrm{Fe}_{3} \mathrm{O}_{4}$ and high content of amorphous materials.

\subsubsection{Micro morphological structure of the raw materials}

SEM images (Figure 2) of the composition 4 with maximum (10\%, Table 1) content of hazardous CPM content showed that all particles were not chemically bonded, showing only mechanical contacts with each other. They exhibit different particle sizes and shapes, with pores of widely

varying shapes and dimensions. Galvanic glass particles consist of almost-perfect spheres with diameters between 10 and $400 \mu \mathrm{m}$ and their fragments of different sizes and configurations, resulting from the metal cleaning process.

\subsection{MECHANICAL AND PHYSICAL PROPERTIES OF THE DEVELOPED CERAMICS}

The developed ceramics flexural resistance, water absorption, and linear shrinkage were analyzed

to determine their mechanical and physical properties. XRD, SEM, EDS, and LAMMA methods were used to research the new materials' structure formation processes. Leaching and solubility tests of metals in standard acid solutions were conducted to control the environmental impact of these hazardous wastes use as raw materials.

\subsubsection{Flexural resistances of ceramics sintered at different temperatures}

The CPM contents were studied in the interval of $0-10 \mathrm{wt}$. \% (Table 1) to meet the demands of ceramic producers. Sintering was conducted at temperatures of $700^{\circ}, 750^{\circ}, 800^{\circ}, 850^{\circ}, 900^{\circ}, 950^{\circ}, 1000^{\circ} \mathrm{C}$ for one hour. All the ceramics developed showed flexural resistance between 3.2 and $19.8 \mathrm{MPa}$ after sintering at all temperatures.

Table 1 - Flexural resistance of the ceramics, sintered at different temperatures. 


\begin{tabular}{|lllllllllll|l|}
\hline \multicolumn{3}{|c|}{$\begin{array}{l}\text { Compositions, } \\
\text { wt. \% }\end{array}$} & \multicolumn{7}{c|}{$\begin{array}{l}\text { Flexural resistance (MPa) of ceramics sintered } \\
\text { at different } \mathrm{T}{ }^{\circ} \mathrm{C}\end{array}$} \\
\cline { 2 - 12 } № & CPM & CSM & GW & 700 & 750 & 800 & 850 & 900 & 950 & 1,000 \\
\hline 1 & 3 & 92 & 5 & 4.3 & 5.6 & 7.0 & 8.3 & 10.2 & 12.8 & 13.1 \\
\hline 2 & 5 & 88 & 7 & 5.4 & 6.2 & 7.9 & 10.3 & 11.8 & 13.0 & 15.8 \\
\hline 3 & 7 & 83 & 10 & 6.3 & 7.1 & 9.4 & 11.8 & 12.9 & 14.5 & 16.3 \\
\hline 4 & 10 & 80 & 10 & 6.5 & 7.3 & 11.2 & 11.8 & 14.3 & 14.5 & 15.5 \\
\hline 5 & 8 & 86 & 6 & 5.8 & 6.9 & 8.7 & 10.6 & 11.8 & 12.9 & 14.3 \\
\hline 6 & 0 & 90 & 10 & 4.1 & 5.4 & 8.2 & 14.5 & 16.9 & 17.6 & 19.8 \\
\hline 7 & 0 & 100 & 0 & 3.2 & 5.3 & 8.8 & 9.6 & 11.6 & 12.5 & 14.0 \\
\hline
\end{tabular}

The ceramics' resistances increased along with the temperature until $1,000^{\circ} \mathrm{C}$. In the range of $950^{\circ}-1,000^{\circ} \mathrm{C}$, the decrease in the resistance values due to excessive melting of the test samples was clearly visible with the rounding of the samples' edges and corners for all compositions. Further increase of temperature would result in the complete melting of the test samples with the loss of their shape. Only composition 7 (the traditional clay-sand mix) practically stopped gaining strength at $1050^{\circ} \mathrm{C}$, indicating the inevitability of its excessive melting with a further increase in temperature.

All ceramics sintered at almost all temperatures (except compositions 1 and 2 at $800^{\circ}-950^{\circ} \mathrm{C}$ ) showed higher resistance than the traditional composition 7. This fact demonstrates the positive influence of some industrial wastes on the ceramics' resistance, unlike Castro (2010) and Kunz et al. (2002), who used textile mud to manufacture ceramic with reduced resistance due to increased waste content. The best performance of composition 6 resistance regarding ceramics $7(19.8$ versus $15.0 \mathrm{MPa})$ was noted at $1,000^{\circ} \mathrm{C}$.

CPM addition up to 7 and 10\%, keeping GW content equal (10\%) (compositions 3 and 4 ) led to a

significant increase in the ceramics' resistance compared to ceramic 6 in the range $700^{\circ}-800^{\circ} \mathrm{C}$. However, at $850^{\circ} \mathrm{C}$, this preeminence was lost, possibly due to an increase in gas formation by CPM's organic components.

Comparison of resistance values of clay-sand ceramics (composition 7) with those with CPM content between $3-10 \%$ (compositions 1-5) showed that only 5 out of 35 resistance results were slightly lower (in the range of $750^{\circ}-1,000^{\circ} \mathrm{C}$ of the composition 1 , before the excessive melting at $1,050^{\circ} \mathrm{C}$ ) than those of composition 7. For the remaining 30 results, the superior resistance of ceramics with 3-10\% CPM reached 14.3 versus $11.6 \mathrm{MPa}$ (composition 4 at $900^{\circ} \mathrm{C}$ ) or 14.5 versus $12.5 \mathrm{MPa}$ (composition 3 and 4 at $950^{\circ} \mathrm{C}$ ).

These experimental data granted a positive evaluation of the impact of hazardous CPM on the resistance of ceramics. The best explanation for this phenomenon might be the fact that CPM has an exceptionally high $\mathrm{Zn}$ content $(20.28 \%)$ with a significantly reduced melting point $\left(419^{\circ} \mathrm{C}\right)$ and relatively small amounts of other heavy metals with low melting points - $\mathrm{Sn}\left(232^{\circ}\right), \mathrm{Pb}\left(324^{\circ} \mathrm{C}\right)$ and with the inclusion of the well-known fluxes 
$\mathrm{K}_{2} \mathrm{O}, \mathrm{Na}_{2} \mathrm{O}, \mathrm{SO}_{3}$, which also contribute to the growth of resistance of the samples after calcination at low temperatures with total encapsulation of heavy metals. However, almost half of the CPM chemical composition consists of organic components with C.L. $=39.11 \%$.

Common bottle glass waste (GW) has a melting point of $700^{\circ}-750^{\circ} \mathrm{C}$. This material content increase from 5 , 6, and 7 wt.\% (compositions 1, 2, and 5) to 10\% (compositions 3, 4, and 6) led to

an increment in resistance until 14.5 and $17.6 \mathrm{MPa}$ at $950^{\circ}$ and $19.8 \mathrm{MPa}$ at $1,000^{\circ} \mathrm{C}$. Such melting of the CPM and GW particles imparted mechanical adherence of clay particles or full encapsulation of the heavy metals' particles with molten material.

As stated in the Brazilian technical standard NBR 15,270-3 (2005), solid bricks are classified regarding their flexural resistance as follows: Class A < 2.5 MPa; Class B 2.5-4.0 MPa; and Class C > 4.0 MPa. That infers that the developed ceramics exceeded Class $A$ requirements of national standards already at a minimum temperature of $700^{\circ} \mathrm{C}$; with further increases in the firing temperature, the resistance steadily grew to the beginning of the excessive melting of materials at

$1000^{\circ} \mathrm{C}$.

All new ceramics containing CPM and GW showed higher flexural resistance values at all temperatures than traditional ceramics 7. This improvement in the developed compositions' resistance values at low temperatures might be desirable for industrial enterprises as it provides a better quality product without increasing the thermal energy consumption. Thus, both industrial wastes act as intensifiers of the structure formation processes of the developed ceramic materials. The test samples' flexural resistance' standard deviation values varied between $0.4-0.9 \mathrm{MPa}$ and increased with increasing sintering temperature.

\subsubsection{Water absorption $\left(\mathrm{W}_{\mathrm{A}}\right)$ of ceramics sintered at different temperatures}

The results of the water absorption test (Table 2) correlate with the number of open pores. Therefore the $\mathrm{W}_{\mathrm{A}}$ values steadily decreased with the increase in the sintering temperature and partial melting of the test samples. Composition 6 presented the lowest $\mathrm{W}_{\mathrm{A}}(3.73 \%)$ at the highest acceptable temperature (without excessive melting, $1,000^{\circ} \mathrm{C}$ ) with it increasing till $5.80 \%$ at $1.050^{\circ} \mathrm{C}$ as the pores invreaing due to excessive melting , followed by ceramics 4 (6.93\%) and ceramics $3(7.98 \%)$, a finding utterly consistent with the flexural resistance values (Table 3). The ceramic test samples from the traditional clay-sand mix - composition 7 exhibited the highest $\mathrm{W}_{\mathrm{A}}(11.79 \%)$ due to the absence of fluxes elements of CPM and GW. Ceramics 1 with the lowest CPM content (3\%) and 5\% GW content ranked second in higher $\mathrm{W}_{\mathrm{A}}$ (Table 2), followed by ceramics 2 with 5\% and 7\% CPM and GW contents correspondingly.

Table 2 - Water absorption of ceramic compositions at different firing temperatures 


\begin{tabular}{|c|c|c|c|c|c|c|c|c|c|c|}
\hline \multirow[t]{2}{*}{ № } & \multicolumn{3}{|c|}{ Compositions content, wt.\% } & \multicolumn{7}{|c|}{ Water absorption (\%) of ceramics at different $\mathrm{T}^{\circ} \mathrm{C}$} \\
\hline & CPM & CSM & GW & 700 & 750 & 800 & 850 & 900 & 950 & 1,000 \\
\hline 1 & 3 & 92 & 5 & 25.17 & 23.45 & 19.67 & 16.54 & 14.41 & 10.45 & 9.48 \\
\hline 2 & 5 & 88 & 7 & 27.28 & 27.86 & 22.86 & 20.51 & 17.03 & 9.67 & 6.14 \\
\hline 3 & 7 & 83 & 10 & 19.14 & 16.58 & 16.10 & 14.04 & 9.34 & 7.98 & 5.06 \\
\hline 4 & 10 & 80 & 10 & 17.28 & 16.69 & 15.65 & 13.56 & 9.98 & 6.93 & 4.28 \\
\hline 5 & 8 & 86 & 6 & 21.38 & 20.80 & 18.94 & 13.26 & 10.46 & 7.89 & 5.98 \\
\hline 6 & 0 & 90 & 10 & 19.34 & 18.44 & 17.59 & 14.12 & 9.59 & 6.53 & 3.73 \\
\hline 7 & 0 & 100 & 0 & 31.36 & 28.68 & 25.79 & 24.62 & 19.98 & 11.79 & 9.21 \\
\hline
\end{tabular}

To increase water absorption and apparent porosity of ceramics with a decrease in the linear shrinkage values, Ozdemir and Yilmaz (2007) fired samples of clay and blast furnace slag mix at $1150^{\circ}, 1175^{\circ}$, and $1200^{\circ} \mathrm{C}$ for 1 hour.

The standard deviation values of the test samples' water absorption varied between $0.9-1.6 \%$ and increased with increasing sintering temperature.

\subsubsection{Linear shrinkage of ceramics sintered at different temperatures}

Linear shrinkage of the ceramics during sintering is a consequence of drying and sintering of the test samples, burnout of organic impurities, decarbonization, and subsequently, the onset of melting and chemical interaction of melted components.

Table 3 - Linear shrinkage of the ceramics after sintering

\begin{tabular}{|c|c|c|c|c|c|c|c|c|c|c|c|}
\hline \multirow[t]{2}{*}{ № } & \multicolumn{3}{|c|}{ Compositions content, wt.\% } & \multicolumn{7}{|c|}{ Shrinkage (\%) of ceramics at $\mathrm{T}^{\circ} \mathrm{C}$} & \multirow{2}{*}{$\mid \begin{array}{l}\text { These } \\
\text { mentioned } \\
\text { processes led }\end{array}$} \\
\hline & CPM & CSM & GW & 700 & 750 & 800 & 850 & 900 & 950 & 1,000 & \\
\hline 1 & 3 & 92 & 5 & 1.08 & 1.93 & 2.04 & 2.05 & 5.29 & 6.29 & 11.67 & to a steady \\
\hline 2 & 5 & 88 & 7 & 1.13 & 1.60 & 2.17 & 3.28 & 5.14 & 6.02 & 12.05 & increase in the \\
\hline 3 & 7 & 83 & 10 & 0.96 & 1.08 & 1.92 & 2.98 & 4.30 & 5.24 & 5.93 & shrinkage \\
\hline 4 & 10 & 80 & 10 & 0.74 & 1.00 & 1.20 & 1.44 & 3.32 & 4.15 & 10.12 & values with an \\
\hline 5 & 8 & 86 & 6 & 1.07 & 1.17 & 2.22 & 3.48 & 3.88 & 5.87 & 7.09 & $\operatorname{case}$ \\
\hline 6 & 0 & 90 & 10 & 0.33 & 0.60 & 0.81 & 1.02 & 5.29 & 7.86 & 6.83 & in the firing \\
\hline 7 & 0 & 100 & 0 & 1.24 & 2.46 & 3.74 & 4.34 & 5.85 & 8.89 & 12.45 & the range of \\
\hline
\end{tabular}

$700^{\circ}-1,000^{\circ} \mathrm{C}$

(Table 3). The ceramics with maximum GW and CPM content (composites 4, 3, and 5) exhibited the lowest 
shrinkage values after firing at $950^{\circ} \mathrm{C}(4.15,5.24$, and 5.87\%, correspondingly), followed by ceramics 2 (6.02 $\%)$ and 1 (6.29\%). Ceramics 6 with $10 \%$ GW content showed an almost maximum shrinkage value (7.86\%), only lower than traditional clay-sand mix's - composition 7 (8.89\%). The incorporation up to 5 wt. \% of GW decreased the linear shrinkage, open porosity and bulk density of the bricks in comparison with the fired clay used as a control (Pérez-Villarejo, et al., 2015). The combination of two effects might explain this order of increase in shrinkage values: 1 . melting of the components with increasing temperature and the inevitable shrinkage during cooling, and 2. an increase in the samples' volume during gas formation as a result of the burning of organic components of CPM and clay, separation of hydrated groups from clay minerals of the initial mixture.

The standard deviation values of the test samples' linear shrinkage ranged between $0.3-0.7 \%$ and increased with increasing sintering temperature.

\subsection{Physicochemical process of ceramics structure formation}

The studies of the physicochemical process of the developed ceramics' structure formation were conducted using the XRD, SEM, and EDS techniques with the ceramics 4 since it showed the best values of flexural resistance, water absorption, and linear shrinkage after sintering at $700^{\circ}$ and $950^{\circ} \mathrm{C}($ Tables 1 - 3). Therefore, all structure formation processes of these materials should be most pronounced and unambiguously established.

\subsubsection{Changes in mineralogical composition during ceramics structure formation}

Through XRD analysis (Figure 3-A), the mineral composition of ceramics 4 after sintering at $700^{\circ} \mathrm{C}$ for one hours revealed the invariability of the mineral composition in comparison with Figure 1 before firing, namely clay mineral illite $\mathrm{KAl}_{2} \mathrm{Si}_{3} \mathrm{AlO}_{10}(\mathrm{OH})_{2}$, magnetite $\mathrm{Fe}_{3} \mathrm{O}_{4}$ and quartz $\mathrm{SiO}_{2}$ with a small increasing of amorphous materials. But after firing at $950^{\circ} \mathrm{C}$ all illite peaks disappeared (Fig. 3-B) due to thermal decomposition of $(\mathrm{OH})_{2}$ group and the appearance of several peaks of mullite $\mathrm{Al}_{6} \mathrm{Si}_{2} \mathrm{O}_{13}$. Similar thermal decomposition of the thenardite was observed by Vidya and Lakshminarasappa (2013). A high X-ray background on the XRD is visible evidence of the high content of an amorphous glassy phase due to the foundry process during the mixtures' heating at $750^{\circ}$ and $950^{\circ} \mathrm{C}$. New structures formed by the new amorphous glassy formations might explain all the changes in the developed ceramics' mechanical and chemical properties. The low maximum intensity of the quartz crystalline peaks (400 cps - counts per second) and the much lower intensity of all other minerals indicates a low content of these crystalline bodies in the samples and their crystal structures imperfection. Therefore, their effect on mechanical and physical properties can only be remarkably insignificant. All these properties are a consequence of the amorphous glassy materials in the samples.

\subsubsection{Changes in the micro-morphological structure during ceramics' sintering}

The analysis of the composition 4 microstructure in three different stages (Fig. 4), obtained by the SEM method at the same 3,000-fold magnification, demonstrated that the initial components' mixture contains particles of different sizes and configurations, without any connection between them (Fig. 4-A). The firing of 
the samples at a temperature of $700^{\circ} \mathrm{C}$ (Fig. 4-B) did not cause an undoubted bonding of the particles to each other, just a slight rounding of their surfaces is noticeable, indicating their melting's beginning.

B - mixture after sintering at $\mathrm{T}^{\circ}=700^{\circ}$ and $\mathrm{C}$ - at $950^{\circ} \mathrm{C}$ for 6 hours.

With the increase in the firing temperature up to $950^{\circ} \mathrm{C}$ (Fig. 4-C), vast fields of molten materials became visible, and all particles were covered by a uniform layer of a dense glass-like structure with few pores. It is assumed that these pores were formed due to the release of combustion gases from CPM's organic components (oil, paints, resins, and other wastes) or chemical interaction of the smelted initial components. During the study of numerous samples by the SEM method, shapes similar to crystal bodies were not found. A small number of crystalline forms, established using the XRD method (Fig. 3-B and C), is covered by a layer of amorphous neoformations, being masked by it. This fact endorses the hypothesis about the new amorphous glassy formations' predominant role, explaining the developed ceramic materials' strengthening process and all their observed properties.

\subsubsection{Chemical composition of the new formations of developed ceramics by the EDS and}

\section{LAMMA methods}

The results of studying the new formations that strengthen ceramics and determine their structure and properties, by the EDS method (Fig 4-C and Table 7), have shown a high level of heterogeneity in their chemical composition at the micro-level. There is no repetition in the chemical composition, no similarity in the percentage amount of any elements in any of the points,

Table 7 - Chemical compositions (wt.\%) of ceramics' 4 at different points by the EDS method after sintering at $950^{\circ} \mathrm{C}$ (Figure 5-C).

\begin{tabular}{|c|c|c|c|c|c|c|c|c|c|c|c|}
\hline \multirow[t]{2}{*}{ Points } & \multicolumn{11}{|c|}{ Chemical compositions of different areas and points (wt. \%) } \\
\hline & $\mathrm{Mg}$ & Al & Si & $S$ & $\mathrm{Cl}$ & $\mathrm{Ca}$ & $\mathrm{Ti}$ & $\mathrm{Cr}$ & $\mathrm{Fe}$ & $\mathrm{Zn}$ & Total \\
\hline 1 & 0.98 & 16.17 & 4.03 & 14.25 & 0.16 & 22.68 & 28.60 & 11.11 & 0.95 & 1.07 & 100.0 \\
\hline 2 & 10.44 & 8.17 & 21.63 & 11.26 & 0.24 & 17.69 & 22.86 & 7.57 & 0.06 & 0.08 & 100.0 \\
\hline 3 & 4.35 & - & 9.52 & 15.56 & 11.46 & 44.15 & 0.63 & 0.24 & 8.56 & 5.53 & 100.0 \\
\hline 4 & 6.16 & - & 13.76 & 8.26 & 3.75 & 29.30 & 10.74 & 15.21 & 10.69 & 2.13 & 100.0 \\
\hline 5 & 13.11 & 12.59 & 8.30 & 12.31 & 4.52 & 12.62 & 15.90 & 3.85 & 15.62 & 1.18 & 100.0 \\
\hline 6 & 11.02 & 19.56 & 27.48 & 17.05 & 0.49 & 09.22 & 6.17 & 0.47 & 8.54 & - & 100.0 \\
\hline 7 & 8.06 & - & 12.18 & 10.23 & 0.72 & 31.50 & 8.97 & 19.26 & 6.65 & 2.43 & 100.0 \\
\hline
\end{tabular}

neither in 1-2-3 and 4-5 that are closer to each other nor in 6 and 7 that are far from them. The main reason for such high heterogeneity is the practical impossibility of obtaining a high homogeneity of the initial components' mix at the micro-level before their hydration and 
compaction. A similar heterogeneity in the isotopes' composition (Fig. 5) of the new formations at

the six points closest to each other was also detected using laser micro-mass analysis (LAMMA).

All points had different sets of isotopes with different peak heights, reflecting their different percentage at each of these points. Such a difference in the isotopic composition of the nearest points indicates the amorphism of these new ceramics' formations, which entirely agrees with the EDS method's results.

\subsection{Leaching and solubility of the developed ceramics}

The analysis of the solubility and leaching lixiviation values obtained experimentally for CPM and test samples of composition 4 (Table 8) demonstrated the efficiency of heavy metals bonding to insoluble conditions and compliance of the obtained results with the Brazilian national standard requirements NBR 10,004 (2004).

Table 8 - Comparison of metals' solubility and leaching values from CPMand ceramics 4 with Brazilian sanitary norms, after sintering at $950^{\circ} \mathrm{C}$.

\begin{tabular}{|lllllll|}
\hline \multirow{2}{*}{ Elements } & \multicolumn{5}{l}{ Solubility } & \multicolumn{4}{l|}{ Leaching } \\
\cline { 2 - 7 } & NBR & CPM & Ceram. 4 & NBR & CPM & Ceram. 4 \\
\hline $\mathrm{Al}$ & 0.2 & 2148 & 0.1 & 0.2 & 1528 & 0.1 \\
$\mathrm{Cd}$ & 0.005 & $<0.28$ & $<0.001$ & 0.005 & $<0.28$ & $<0.001$ \\
\hline $\mathrm{Pb}$ & 0.01 & 83.56 & $<0.1$ & 0.01 & 98.24 & $<0.1$ \\
\hline $\mathrm{Cu}$ & 2.0 & 66.39 & $<0.005$ & 2.0 & 69.95 & $<0.005$ \\
$\mathrm{Cr}$ & 0.05 & 135.16 & $<0.01$ & 0.05 & 141.75 & $<0.01$ \\
\hline $\mathrm{Sn}$ & - & 417.38 & $<0.01$ & - & 507.51 & $<0.01$ \\
\hline $\mathrm{Fe}$ & 0.3 & 27.54 & $<0.05$ & 0.3 & 16.76 & $<0.05$ \\
\hline $\mathrm{Mn}$ & 0.1 & 7.374 & 0.01 & 0.1 & 4552 & 0.01 \\
\hline $\mathrm{Zn}$ & - & 28.075 & $<0.002$ & - & 19073 & $<0.002$ \\
\hline $\mathrm{Ba}$ & 0.7 & 38.12 & $<0.001$ & 0.7 & 41.64 & $<0.001$ \\
\hline $\mathrm{Ni}$ & 0.2 & 8352 & 0.06 & - & $5,572.85$ & 0.06 \\
\hline
\end{tabular}

Note: " NBR " means that these elements' content limit has not yet been established in the Brazilian norms NBR 10,004 (2004).

Comparing the obtained results with the standard shows a wide safety margin in these numbers for almost all elements, especially for heavy metals. Comparing the obtained results with the standard shows a wide safety margin in these numbers for almost all elements, especially heavy metals. The ceramic manufacturing process undoubtedly enabled the reliable chemical binding of hazardous elements of the 
studied raw materials to insoluble condition even at relatively low temperatures $\left(950^{\circ} \mathrm{C}\right)$ of industrial production. Jordán, et al. (2005) also achieved a similar effect of heavy metals bonding in red ceramics by incorporating sewage mud.

The developed compositions and technology might be used for the production of solid or holed bricks or blocks. Based on the results of solubility and leaching tests (Table 8), it is possible to state that the materials developed can be successfully recycled at the end of their service life as valuable components of new materials (NBR 10,004 (2004).

\section{Conclusions}

The obtained experimental results proved the feasibility of applying industrial automobile production mud (CPM) with high contents of heavy metals $(\mathrm{Ni}, \mathrm{Zn}, \mathrm{Pb}, \mathrm{Sn}, \mathrm{Cr}$, and $\mathrm{Cu}$ ) to produce

red ceramics in combination with galvanic process glass waste and traditional mixtures of natural materials (red clay and sand). Being fired in the temperature range of $700^{\circ}$ and $950^{\circ} \mathrm{C}$, the flexural resistance values reached $17.6 \mathrm{MPa}$ at $950^{\circ} \mathrm{C}$. The developed ceramics' water absorption values, sintered at $950^{\circ} \mathrm{C}$, varied between 6.53 and $10.45 \%$, linear shrinkage - between 5.24 and $6.29 \%$, density $-2.7-3.2 \mathrm{~g} / \mathrm{cm}^{3}$, and dilatation coefficient between 5.3 and $13.8 \%$. The scrutiny of the physical-chemical processes of the ceramics' structure formation revealed the synthesis of mullite $\mathrm{Al}_{6} \mathrm{Si}_{2} \mathrm{O}_{13}$ with partial melting of all components' surface and the formation of predominantly glassy materials that closed the samples' pores and bonded the not melted particles' cores. The high heavy metal content in car production mud and galvanic glass waste led to the intensification of the mechanically and chemically more robust structure formation processes. Production of these materials is economically attractive due to the use of free raw materials or additional payment from companies to use their hazardous industrial waste. However, this study's most significant impact is on the environment due to the prevention of pollution and the reduction of nature destruction by a large number of quarries for the extraction of traditional construction materials.

\section{Declarations}

\section{ACKNOWLEDGMENTS}

The authors are grateful to the LAMIR-UFPR for technical assistance in XRD and XRF analyses.

\section{DECLARATIONS}

a. Funding - our research never was supported

b. Conflicts of interest - We declare absence any conflicts of interest

c. Availability of data and material - Our data are transparent

d. Code availability - No applicable

e. Ethics approval - We had no clinical trials and research using animals 
f. Consent to participate - Full consent

g. Consent for publication - Full consent

h. Authors' contributions

Vsévolod Mymrin - author of the idea, developer of the plan of the experiments, participant of all stages of research, author of the first version of the manuscript

Federal Technological University of Paraná

Kirill Alekseev - performer of LAMMA analyses, co-author of this manuscript

Federal Technological University of Paraná

Monica A. Avanci - performer of all laboratory experimental works, co-author of this manuscript

Federal Technological University of Paraná

Paulo H.B. Rolim - performer of all laboratory experimental works, co-author of this manuscript.

Federal Technological University of Paraná

Cleber L. Pedroso - bibliographical revision and performer of XRD analyses

Federal Technological University of Paraná

Daniela E. Pedroso - bibliographical revision and performer of SEM analyses

Federal Technological University of Paraná

\section{References}

1. Asavapisit S, Chotkland D (2004) Solidification of electroplating mud using alkali-activated pulverized fuel ash as cementitious binder. J Cem Concr Res 34:349-353

2. Bai J et al (2014) Preparation of foam glass from waste glass and fly ash. J Mat Lett 136:52-54

3. Barreto LSS et al (2020) Reuse of ornamental rock-solid waste for stabilization and solidification of galvanic solid waste: Optimization for sustainable waste management strategy. J Clean Prod 275:122996. https://doi.org/10.1016/j.jclepro.2020.122996

4. Basegio TM et al (2001) Environmental Aspects of the Use of Tannery Mud as Raw Materials for Ceramics Red. Proceedings of the 45th Brazilian Congress on Ceramics. Florianópolis, SC, Brazil

5. Casagrande MN (2002) Effect of the addition of fire-clay and semi-vitrified materials on the physical behavior of bulk ceramic of pavement. Dissertation, Federal University of Santa Catarina, Florianopolis, Brazil 
6. Castro TM (2010) Solidification/Stabilization of mud textile for manufacturing of ceramic acoustic blocks. Study of compression resistance and water absorption. Dissertation, University of UEM, Maringa, Brazil

7. El-Ashtoukhy E-S, Z et al (2020) Intensification of a new electrocoagulation system characterized by minimum energy consumption and maximum removal efficiency of heavy metals from simulated wastewater. J Chem Eng Proc - Proc. Inten.154,108026. https://doi.org/10.1016/j.cep.2020.108026

8. Fraissler $\mathrm{G}$ et al (2009) Influence of dry and humid gaseous atmosphere on the thermal decomposition of calcium chloride and its impact on the remove of heavy metals by chlorination. J Chem Eng Proc \& Proc. Intens 48:380-388

9. https://doi.org/10.1016/j.cep.2008.05.003

10. Gorospe K et al (2019) Effect of various glass aggregates on the shrinkage and expansion of cement mortar. J Con Build Mat 210:301-311

11. https://doi.org/10.1016/j.conbuildmat.2019.03.192

12. Ji R et al (2019) Utilization of mineral wool waste and waste glass for synthesis of foam glass at low temperature. J ConBuild Mat 215:623-632

13. https://doi.org/10.1016/j.conbuildmat.2019.04.226

14. Jordán MM et al (2005) Application of sewage mud in the manufacturing of ceramic tile bodies

15. J App Clay Sci 30:219-224

16. Kim K, Kim K, Hwang J (2015) LCD waste glass as a substitute for feldspar in the porcelain sanitary ware production. J Cer Int 41:7097-7102. DOI:10.1016/j.ceramint.2015.02.018

17. Kołodyńska D et al (2020) Evaluation of possible use of the macroporous ion exchanger in the adsorption process of rare earth elements and heavy metal ions from spent batteries solutions

18. J Chem Eng Proc \& Proc. Intens 147:107767. https://doi.org/10.1016/j.cep.2019.107767

19. Kunz A et al (2002) New trends in the treatment of textile effluents. J New Chem 25:78-82

20. Lu J-X et al (2019) Co-utilization of waste glass cullet and glass powder in precast concrete products. J Con Buil Mat 223:210-220. https://doi.org/10.1016/j.conbuildmat.2019.06.231

21. Mymrin V et al (2015) Red clay application in the utilization of paper production sludge and scrap glass to fabricate ceramic materials. J Appl Clay Sci 107:28-35. DOI:10.1016/j.clay.2015.01.031

22. NBR 15,270-3 (2005) Flexion resistance strength and water adsorption measurements of ceramic bricks, Rio de Janeiro, Brazil

23. NBR 10,004 (2004) Solid wastes: classification. Rio de Janeiro, Brazil

24. Ozdemir I, Yilmaz S (2007) Processing of unglazed ceramic tiles from blast furnace slag. J Mat Proc Tech 183:13-17

25. Pérez-Villarejo L et al (2015) Valorization and inertization of galvanic sludge waste in clay bricks. J Appl Clay Sci 105:106:89-99. https://doi.org/10.1016/j.clay.2014.12.022

26. Phonphuak K et al (2016) Utilization of waste glass to enhance physical-mechanical properties of fired clay brick. J Clean Prod 112:3057-3062. doi.10.1016/j.jclepro.2015.10.084 
27. Starý M et al (2019) Summary of the properties and benefits of glass mechanically frosted with an abrasive brush. J Con Buil Mat 206:364-374

28. https://doi.org/10.1016/j.conbuildmat.2019.02.062

29. Szyczewski P et al (2009) Res Heavy Metals in Poland. Polish J Env Stud 18:755-768

30. Usai G (2003) Industrial wastes and by products a massive reuse in ceramic industry

31. Ceramurgia J 33:1-13

32. Vidya YS, Lakshminarasappa BN (2013) Preparation, characterization, and luminescence properties of orthorhombic sodium sulphate. J Phys Res Int 2013: 641631. doi.org/10.1155/2013/641631

33. Ye $\mathrm{C}$ et al (2015) Preparation and properties of sintered glass-ceramics containing Au-Cu tailing waste. J Mat Design 86:782-787. http://dx.doi.org/10.1016/j.matdes.2015.07.173

34. Zhu M et al (2016) Preparation of glass ceramic foams for thermal insulation applications from coal fly ash and waste glass. J Con Build Mat 112:398-405. 10.1016/j.conbuildmat.2016.02.183 DOI

35. We Y-L et al (2014) Recycling steel-manufacturing slag and harbor sediment into construction materials. J Haz Mat 265:253-260. doi:10.1016/j.jhazmat.2013.11.049

\section{Figures}

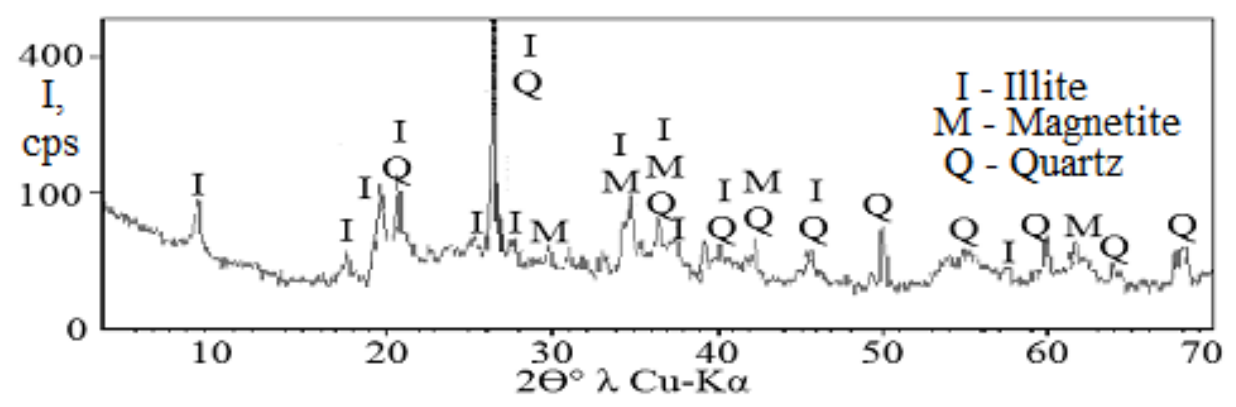

Figure 1

X-ray diffractogram patterns of the ceramics 4 initial dry mix

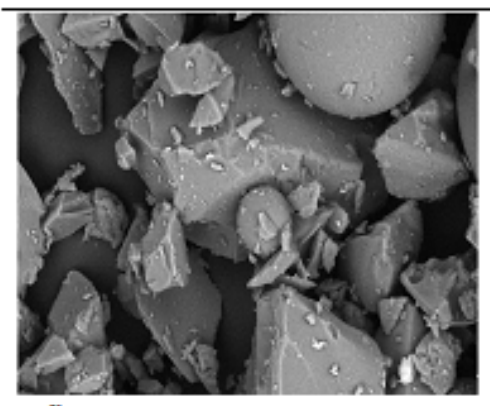

$\mathrm{A}^{\mathrm{x}} 3,000-5 \mu \mathrm{m}$

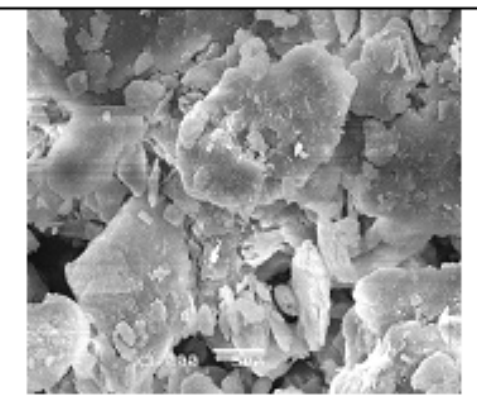

$\mathrm{B}^{\mathrm{x}} 3,000-5 \mu \mathrm{m}$

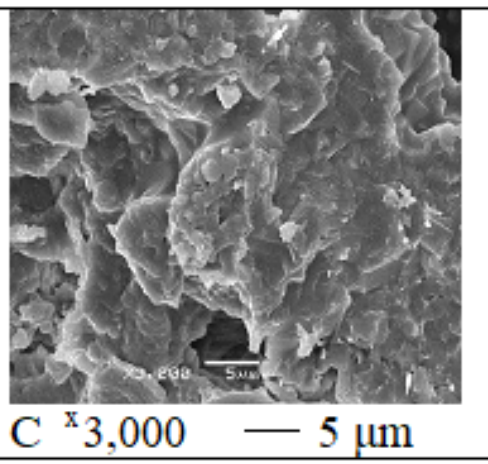

Figure 2

SEM micro-image of the composition 4: A - dry mix, B - after sintering at $700^{\circ} \mathrm{C}$ and $\mathrm{C}-950^{\circ} \mathrm{C}$ for one hour. 


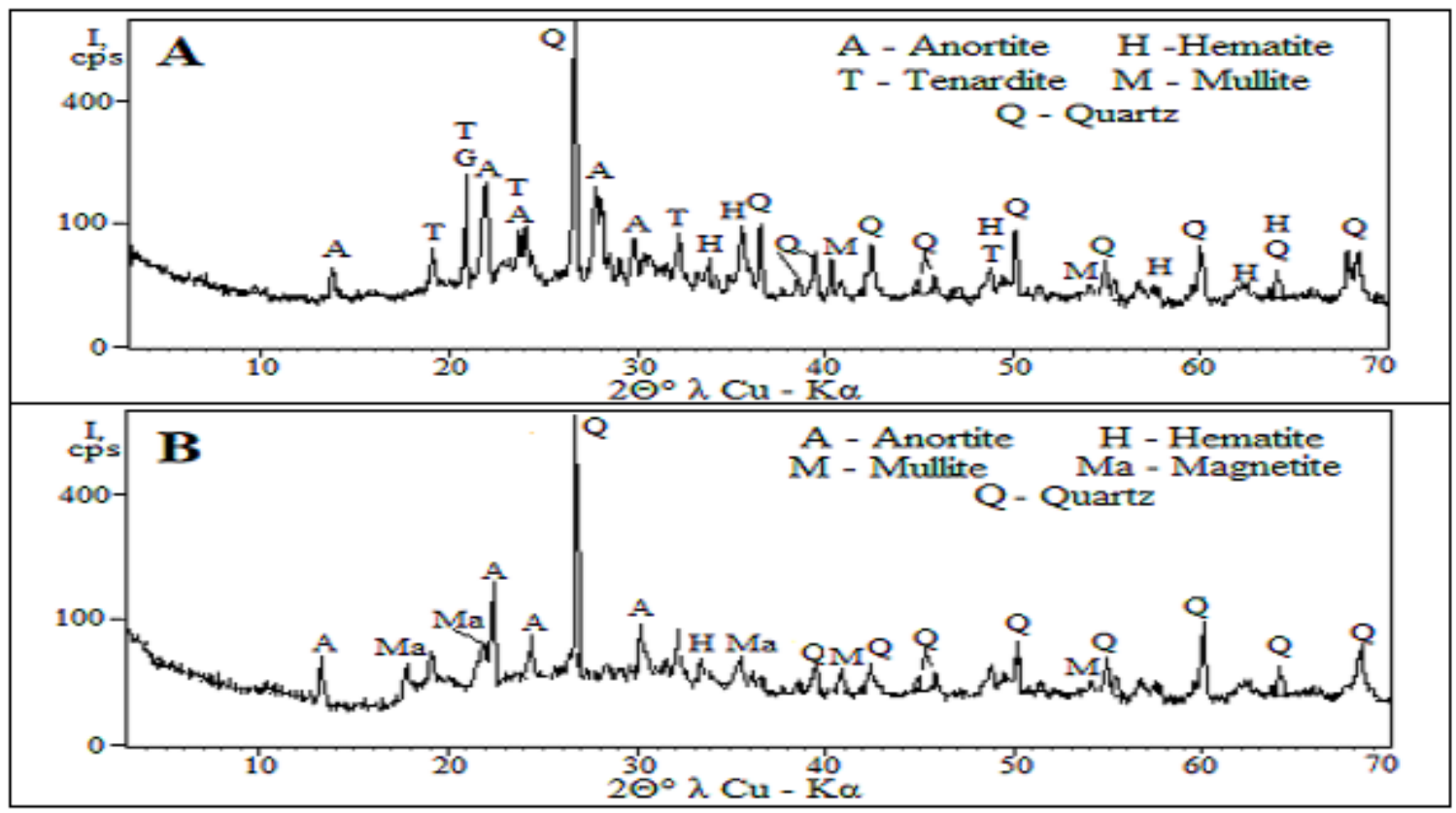

Figure 3

X-ray diffractogram patterns of the ceramics 4 : A - after sintering at $700^{\circ} \mathrm{C}$ and $\mathrm{B}-950^{\circ} \mathrm{C}$ for one hour.

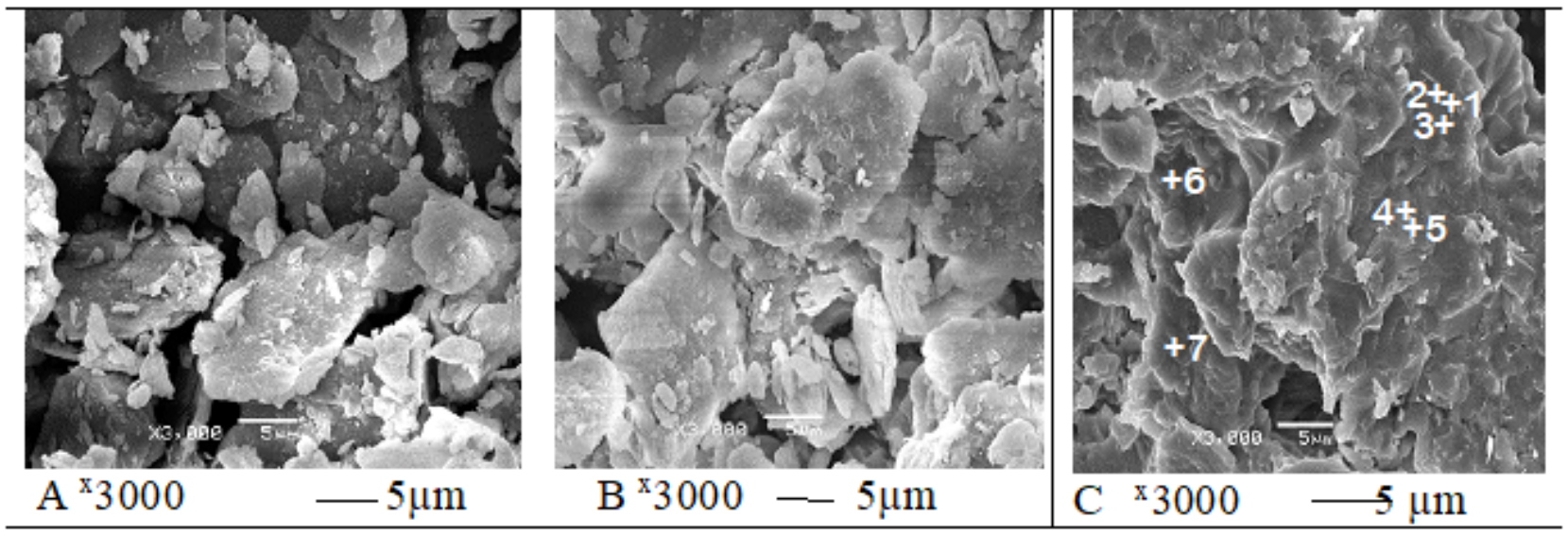

Figure 4

SEM microstructures: A - initial mixture of composition 4; B - mixture after sintering at $\mathrm{T}^{\circ}=700^{\circ}$ and $\mathrm{C}$ - at $950^{\circ} \mathrm{C}$ for 6 hours. 


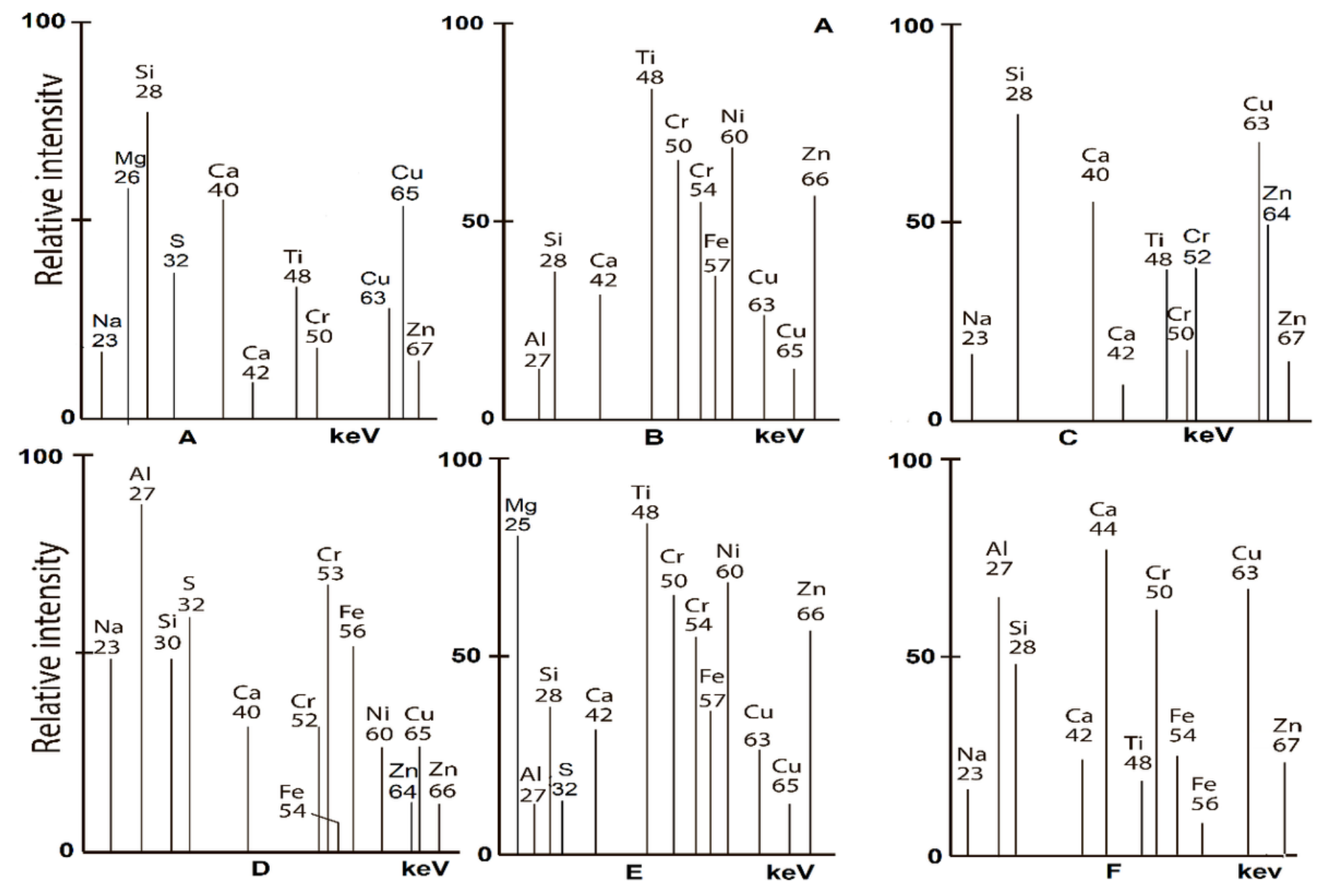

Figure 5

Isotopic compositions (wt.\%) of ceramics 4's closest points by the LAMMA method after sintering at $950^{\circ} \mathrm{C}$ 